\title{
Internationalization in Tertiary Education: Intra-European Students Mobility
}

\author{
Nikos P. Rachaniotis \\ Hellenic Open University, Patras, Greece \\ Filareti Kotsi \\ Zayed University, Dubai, UAE \\ George M. Agiomirgianakis \\ Hellenic Open University, Patras, Greece
}

\begin{abstract}
The enhanced internationalization and mobility of European students reflects an undoubtedly important aspect of human capital investment. This paper examines the internationalization of European students in tertiary education and the factors that determine the probability of a student moving to a European country other than their own. The main goals of the Bologna Process and a framework of definitions of student mobility are presented, as well as factors that may motivate and hamper this process. A linear regression model of the market shares of intraEuropean students and a linear regression model of the ratios of foreign incoming/outgoing students of European countries are estimated. Finally, a Classification and Regression Tree (CART) algorithm is applied in order to explain the reasoning behind the decisions of students for long-term study abroad. The paper suggests that policy measures towards increasing student mobility flows will extend economic integration of the countries involved via human capital development and are most likely to increase present and future economic flows in a tangible way.
\end{abstract}

JEL Classifications: J24, F22, I23

Key words: Educational Economics, Human Capital, Tertiary Education, Student Mobility, Foreign/International Student, Linear Regression Analysis, CART Algorithm

\footnotetext{
* Corresponding Author: Nikos P. Rachaniotis; School of Social Sciences, Hellenic Open University, 57-59 Bouboulinas Str., 26222, Patras, Greece; Tel: +30 6938187625, E-mail: nraxan@unipi.gr.

Co-Author: Filareti Kotsi; Zayed University, College of Communication \& Media, P.O. Box 19282, Dubai, UAE; Tel: +971 44021554, Fax: +971 44021016, E-mail: Filareti.Kotsi@zu.ac.ae;

George M. Agiomirgianakis; School of Social Sciences, Hellenic Open University, 57-59 Bouboulinas Str., 26222, Patras, Greece; Tel: +30 2610362554, Fax: +30 2610367442, E-mail: gmagios@eap.gr. 


\section{Introduction}

In the present era of globalization, which requires increased skills and knowledge, competition is higher among economies and individuals, who consider education as an investment that will, on the one hand, hedge them from unemployment and, on the other hand, broaden their present or future work profile. In contrast to a few decades ago, education needs to be characterized by globally accepted high academic standards. Skills and knowledge obtained by a graduate in one country must be accepted and recognized internationally as equivalent. Governments seeking to ensure sustainable economic and social development for their countries are taking measures to promote the adoption of internationally accepted high academic standards and to encourage the exchange and mobility of students.

Mobility is a basic ingredient of the European political and economic unification process for the creation of a unique European identity. In addition to political and sociological reasons favoring mobility, student mobility contributes directly to the process of human capital formation acquired by young people migrating abroad, which in turn may provide tangible economic effects, both in the destination country and country of the origin as stated by Agiomirgianakis (2006), Agiomirgianakis et al. (2004), and Agiomirgianakis and Asteriou (2001). The internationalization of higher education promoted by the related provisions and measures taken by the EU is a prominent example of policy in this direction.

The concept of an international higher education system in the EU stems from a vision of creating an attractive environment where students can study in a variety of European educational institutions, thereby creating mobility and a unique European identity. In 1999 the Bologna reform process committed to building a common framework that would enable students to move freely within the European Higher Education Area (EHEA) and to study outside their home countries while obtaining full recognition for their qualifications. The overall aim of the Bologna reform process is the harmonization of academic structures and the compatibility and comparability of quality assurance standards throughout Europe in conjunction with the breaking down of the existing educational borders in order to make European Higher Education globally competitive, especially compared with the USA (European Students' Union: Bologna with Student Eyes, 2009).

The means to reach this objective is the removal of several barriers hampering the mobility of students, teachers, and researchers across Europe. After thirteen years of developing the EHEA, there are still many uncertainties about the mobility of students and their real incentives and disincentives. Most of the statistical surveys performed until now have been descriptive and qualitative, and, with very few exceptions, have omitted inferential statistical analysis regarding the factors that may affect the mobility of students (Van Bouwel and Veugelers 2010).

In this paper, we examine the internationalization of higher education students, focusing only on the intra-European market. We present descriptive statistical data and a quantitative 
econometric and statistical analysis in an attempt to capture and model any differences regarding the number of students sent and received and the characteristics of countries as net exporters-importers in terms of academic qualifications.

The remainder of the paper is structured as follows. Section II, presents the main goals of the Bologna Process and the definitions of student mobility in tertiary education in Europe. We discuss the problem of data accuracy as well as the motives and barriers that students face regarding their decision to study abroad. In Section III, intra-European internationalization descriptive data are presented considering, in the first case, study periods longer than one academic year, and, in the second case, the mobility of students in the Erasmus framework. In Section IV, a linear regression model of the dependence of mobility on quantitative variables is estimated. In Section V, a Classification and Regression Tree (CART) algorithm is used in order to explain the decisions of students for long-term study in a European Union country other than their own based on quantitative and qualitative factors. To the best of the authors' knowledge, this is the first statistical model that has the objective of estimating the probability of students moving from one European country to another while attempting to capture the reasoning behind their decision in a quantitative way. Finally, Section VI contains some concluding remarks and plausible policy implication measures that could potentially improve cooperation in the EU.

\section{Students' Mobility in Europe}

\section{A. The Bologna Process and its main goals}

The higher education transformation known as the Bologna Process ${ }^{1}$ has already reached its fourteen year crossroad. This declaration was signed in Bologna, Italy on 19 June 1999. Today, the process unites 47 member states and "Bologna" has become a new European higher education brand, recognized in governmental policies, academic activities, and international organizations (Bologna Follow Up Group Report $2003^{2}$ ).

Mobility is one of the core elements of the Bologna Process, enabling the development of international cooperation and giving substance to the European dimension of education. It assists the process of personal development, hedges against unemployment by enhancing employability, and encourages the acceptance of diversity, tolerance, linguistic pluralism, and coexistence with other cultures. It provides an opportunity for students to experience a diverse environment where they can develop competences that offer them an added value in the labor

\footnotetext{
See, e.g. http://www.ond.vlaanderen.be/hogeronderwijs/bologna/about/

${ }^{2}$ http://www.ond.vlanderen.be/hogeronderwijs/Bologna
} 
market. Consequently, higher education can support internationalization through understanding the place of student mobility in the global environment, even though mobility is one of the most complex processes at the individual, institutional, and societal level, as mentioned in Promoting Mobility, ESIB (2007). Harmonization of the Bologna Process is structured through formal declarations of European ministers and summit meetings held every two years where ministers issue their conclusions and recommendations ${ }^{3}$.

At the beginning of the implementation of the Bologna Process in 1999, the goal was set to promote mobility by overcoming obstacles, and this was elaborated on in 2001 by stating that all obstacles to the free movement of students, teachers, researchers, and administrative staff should be removed. In 2003 mobility was seen as the basis for establishing the EHEA, while in 2005 the ministers of education confirmed their commitment to facilitating the portability of student grants and loans. In 2007, the responsibility of individual governments to facilitate the provision of visas and residence and work permits was recognized in order to encourage a significant increase in the number of joint tertiary educational programs. Most recently, a target specifying that $20 \%$ of students graduating in the EHEA should be mobile by 2020 was introduced in 2009.

\section{B. Data accuracy}

Szarka (2003) classified student mobility into "free movers" mobility (referring to students registered at institutions under standard procedures and not through any organized program), and "organized" mobility (referring to mobility encouraged by organized educational programs). In several small size countries, many students study abroad due to the limited provision of courses in their country; Varghese (2008) mentions that those students are sometimes even more than those who choose to remain in their country.

Several descriptive statistical surveys have been carried out presenting tertiary education student mobility. These rely on two institutional data sources, namely Eurostat and Eurostudent.

Eurostat, the statistical office of the EU, has been using three databases for these surveys: the UNESCO-OECD-Eurostat data collection (UOE), the European Union Labor Force Survey, and the European Union Statistics on Income and Living Conditions. OECD (Organization for Economic Co-operation and Development) is a forum where the governments of 30 states cooperate to address the economic, social, and environmental challenges of globalization. The Commission of the European Communities also collaborates with the OECD. Its member countries gather information, develop and apply common definitions and criteria for data quality control and verification, and provide the necessary tools to interpret and report the submitted data. The definitions and methodological requirements are available on the

\footnotetext{
${ }^{3}$ http://www.ond.vlaanderen.be/hogeronderwijs/bologna/about/how_it_works.htm
} 
web ${ }^{4}$.

Eurostudent project collates comparable data on the social and economic conditions of student life in Europe. The Eurostudent III survey was carried out between 2005 and 2008 in $19 \mathrm{EU}$ member states and three countries outside the EU, capturing the life of students by surveying them directly.

Lanzendorf and Teichler (2003) stated that reporting student mobility depends to a large extent on countries' immigration legislation, mobility arrangements, and data availability. The OECD allows countries to define as:

- International students: those who are not permanent residents of their country of study or, alternatively, those previously educated in another country (regardless of citizenship), depending on the most appropriate operational definition in their national context (OECD, 2010). Permanent or usual residence in the reporting country is defined according to national legislation. In practice, this means holding a student visa or permit, or voting in a foreign country. The country of prior education is defined as the country in which students obtained the entry-qualification, i.e. the one required to enroll in their current level of education.

- Foreign students: the non-citizens enrolled in a country (i.e. including some permanent residents as a result of their or their parents' immigration and therefore an overestimate of actual student mobility).

However, it is obvious that these definitions are not perfect and the "best statistics available" are far from the desired level. There is a broad range of problems regarding definitions per se, quality of collected data, etc. In general, statistical information systems can only produce time series during long periods and thus are meaningful over time if the data collection system is not changed according to political fashion. The major problems of current student mobility statistics according to Kelo et al. (2006) are the lack of comprehensive data on "mobility" and the incomplete coverage of short-term mobile students. More specifically:

- Errors occur due to administrative problems, incomplete reporting, possible manipulation of data by the individual institutions of higher education, etc.

- Data might be inaccurate regarding the reporting of tertiary educational institutions. For example, in some countries, a number of tertiary education students are not included in the official education statistics.

- National policies vary substantially regarding part-time students, distance education students, students in short programs not leading to regular diplomas and degrees, students in programs leading to sub-degree certificates and diplomas, students in adult and continuing professional education, students in preparatory courses, participants of language courses and summer schools, students in internships, "guest" students, and finally short-term mobile students.

${ }^{4}$ http://circa.europa.eu/Public/irc/dsis/edtcs/library?=/public/unesco_collection 
- Data quality differs by education levels, which are classified according to the revised International Standard Classification of Education (ISCED) ${ }^{5}$. In general, data quality is high for students in undergraduate programs of tertiary education and master's programs, while short and often vocational programs are less clearly structured and organized and incomplete information is provided for the number of persons preparing for advanced degrees.

- There are cases of double-counted students, e.g. in countries where students can enroll in more than one field of study or when a student is enrolled in two different programs at the same time or at two different institutions of tertiary education.

- There is a lack of data on outwards-mobile students who are not registered in most countries, thus statistics can only be produced if all countries worldwide register inwards-mobile students. In that case, the number of outwards-mobile students of a certain country is calculated by adding up all inwards-mobile students who went from this country to all the other countries.

Regarding the category of foreign students, there are additional sources of errors, and it is still unclear if they actually affect the available data:

- Cross-border educational programs might be handled inconsistently across countries.

- Foreign students could be reported incompletely/inconsistently in general statistics.

- Foreigners may not be considered as foreigners in official registers and statistics after a period of residence, study, or work, even though their nationality has not changed.

- Data on foreign students might be incomplete by sectors.

- Finally, a serious problem in this context is the undercount of short-term mobility.

Practices of recording short stays abroad vary in statistics on foreign students.

The data for foreign students are the only directly comparable data that is available now because not all countries are able to report data on international student mobility. Nevertheless, there is a need for caution in interpreting the results because of the above mentioned problems and the fact that the numbers of foreign students are accumulated based on different timescales as relevant time series are not yet available for study periods of one full academic year or more.

\section{Motives and barriers for European student mobility}

Over the past three decades, the number of students enrolled worldwide outside their country of citizenship has risen dramatically, from 0.8 million worldwide in 1975 to 3.3 million in 2008, a more than threefold increase as illustrated in Figure 1.

${ }^{5}$ www.oecd.org/edu/eag2009 
Figure 1. Long term growth in the number of students outside their country of citizenship (Growth in internationalisation of tertiary education 1975 2008, in milions)

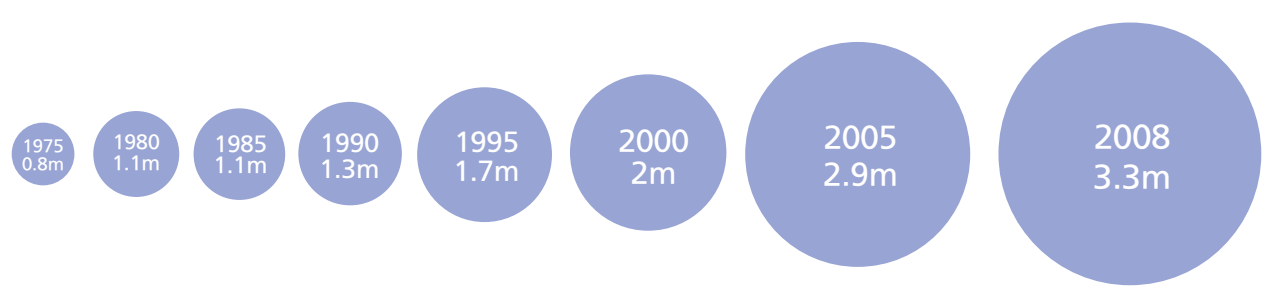

(Note) Data on foreign enrolment worldwide comes from both the OECD and the UNESCO Institute for Statistics (UIS). UIS provided the data on all countries for 1975 1995 and most of the partner countries for 2000, 2005 and 2008. The OECD provided the data on OECD countries and the other partner economies in 2000, 2005 and 2008. Both sources use similar definitions, thus making their combination possible. Missing data were imputed with the closest data reports to ensure that breaks in data coverage do not result in breaks in time series.

(Source) OECD (2010) and UNESCO Institute for Statistics.

The growth of foreign student numbers in tertiary education in Europe can be attributed to several reasons:

- Globalized economies have led to a higher degree of dependency on each other.

- European unification process required harmonization of rules, means and measures that guarantee the mobility of all Europeans.

- EU countries are obliged to treat students from other EU member states as their "home students".

- The wide utilization of new technologies has ensured faster, safer, and in some cases less expensive transportation and communication (OECD, 2010).

The results of the increasing number of mobile European students are obvious in government educational policies. For example, in several countries (e.g. Luxembourg), a studyrelated stay abroad (training course, internship) is mandatory before obtaining a degree in some master programs. In France, engineers are urged to spend time abroad for linguistic reasons, as an acceptable level in English is required to graduate. In Austria, students from polytechnic institutes are required to spend one semester abroad. In a further group of small size European countries, student mobility is intense.

The generic schema of the decision making process of students regarding mobility is illustrated in Figure 2: 
Figure 2. Student mobility decision making process

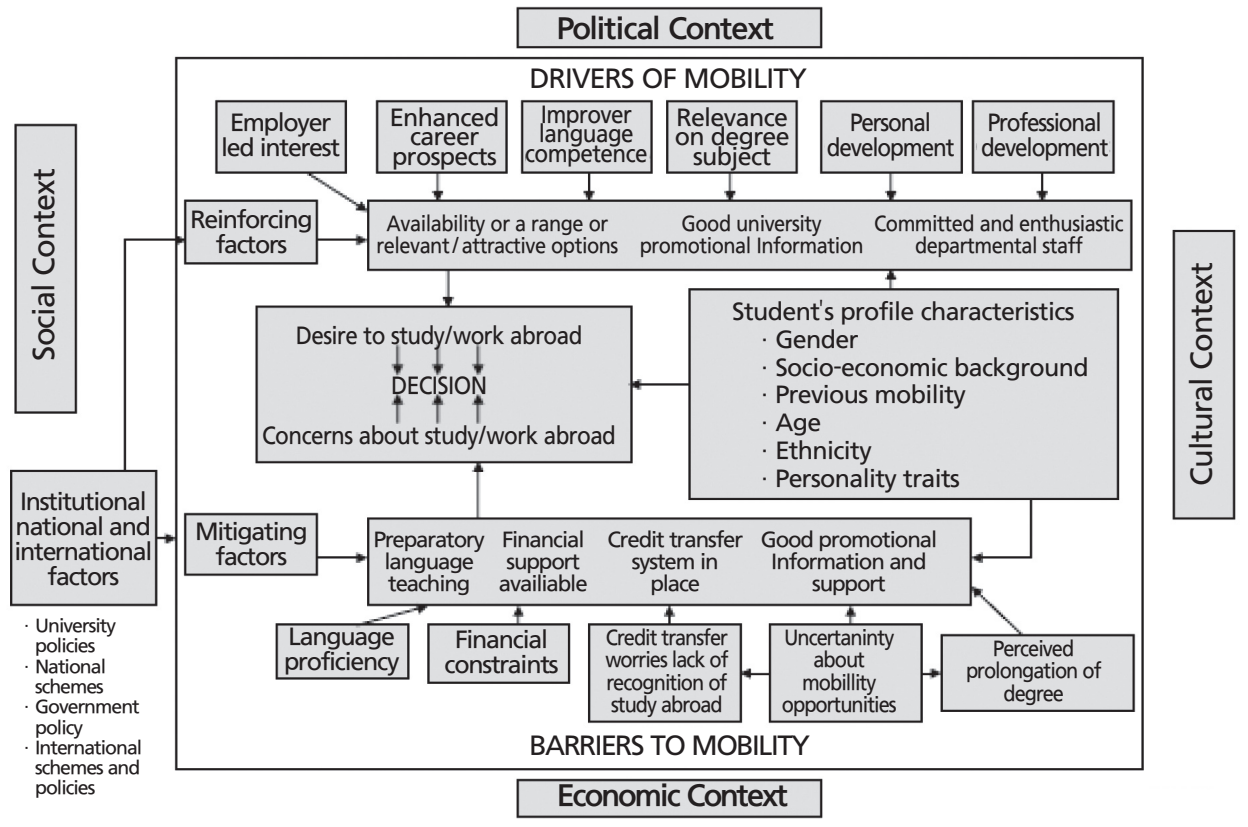

(Source) HEFCE(2004)

From Figure 2, it can be concluded that the drivers and barriers of student mobility can be categorized into those having national-international characteristics and into those based on the personal profile features of students. The major underlying factors that either enhance or discourage students in their choice that were examined in this paper belong to the first group and they are: language, financial aspects, immigration policy/migration networks in host countries, perceived academic superiority of the institutions in the host countries (causing "brain drain" in the origin countries), and geographical-ideological-cultural affinity, as stated in Altbach and Teichler (2001), Altbach and Knight (2007), and Guruz (2008). More specifically:

\section{Language}

The language spoken and used in instruction is an essential element in the choice of a foreign country to study. Countries whose instruction language is widely spoken and read (e.g. English, French, German, and Russian) are leading destinations of foreign students in Europe. The almost universal use of English in scientific literature is unquestionable. Within the non-English speaking countries of Europe, higher education institutions provide an increasing number of classes and even full degree programs taught in English. On the other hand, lack of language proficiency is a major obstacle; therefore, the majority of higher education institutions receiving foreign/international students offer intensive courses in the language of the host country. 


\section{Financial aspects}

A country with a labor market characterized by high wages and low unemployment and with universities offering access to its labor market can attract a larger number of students because of the promising prospects of higher employability and better salary profiles for students after their studies. On the other hand, tuition fees, cost of living, and insufficient support from the home country are also important factors in prospective foreign/international students' choice of country. This tends to lead to inequalities and exclusion of students who do not have additional sources of income.

\section{Impact of immigration policy and migration networks on foreign student destinations}

In recent years, several OECD countries have eased their immigration policies to encourage the temporary or permanent immigration of foreign/international students. Migration networks also play a role. For instance, Portuguese students study in France, Turkish students in Germany, etc.

\section{Academic superiority in the host countries - brain drain in the origin countries}

Key player countries in the foreign/international European student market have education organizations with a long tradition in teaching and research, high credibility for their academic standards, and implement impressive marketing strategies to target potential students. They provide studies at internationally renowned "world-class facilities" with high academic reputations and top positions in the ranking lists of European universities ${ }^{6}$. Verbik and Lasanowski (2007) stated that they have the capacity to provide "better" knowledge than other competitor countries, and this is a major reason why they manage to recruit more foreign/ international students. On the other hand, a brain drain through mobility is mostly feared in those countries that send out more students than they receive from abroad, provided that this accounts for a critical mass of students. For example, the Central and Eastern European countries tend to suffer from a brain drain to Western Europe. Human capital theory argues that a brain drain of highly qualified persons should be prevented because it constitutes an economic factor. Within the EU, it has turned out empirically that any brain drain (often connected to vertical mobility and less to horizontal mobility) is comparatively low, while mobility of highly qualified labor has increased. Kehm (2005) in particular analyzed the fact that the smaller European countries have made efforts to prevent a brain drain while fostering international mobility.

\section{Geographical-cultural-historical factors}

Cultural considerations, geographic proximity, and similarity of education systems are important determinants of the choice of destination. Geographic considerations and similarities

${ }^{6}$ e.g. http://www.timeshighereducation.co.uk/world-university-rankings/2010-2011/europe.html, http://www.arwu.org/Europe2009. 
in entry requirements are likely explanations of the concentration of students, for instance from Germany in Austria, from Belgium in France and the Netherlands, from France in Belgium, between Nordic countries, etc.

Concluding this section, several other factors of the first group that affect student choices that could be examined in future research are: the transparency-flexibility of programs regarding the time spent abroad, the restrictiveness of university admission policies at origin countrie, etc. In addition, factors of the second group include several student profile characteristics like the level of family education separation from the family or from a partner, a possible rejection from national educational systems after failure in examinations, a multiple choice selection of candidate universities in different countries, rejection from the first or second choice.

\section{Intra-European Internationalization data}

\section{A. Long-term study periods}

In Table 1, Foreign students in tertiary education from the 50 European sovereign states are having the 23 European OECD countries and 3 non-OECD European countries (Estonia, Russian Federation, and Slovenia) as a destination in 2008 are depicted. They are also combined by country of origin with each country's respective market share of intra-European foreign students depicted as percentage of enrolled European foreign students. The reason for examining only these 26 European destination countries is that they are the ones with available relevant data and they can be considered to host the major European educational institutions ${ }^{7}$. In Table 1 the symbol $n$ is used in case the magnitude is either negligible or zero. The symbol $a$ is used in case data is not applicable. It has to be noted here that data for Montenegro is incorporated into data for Serbia for the examined time period.

${ }^{7}$ http://www.arwu.org/Europe2009.jsp 
Table 1. Number of foreign students enrolled in tertiary education and percentages of all foreign students from Europe-wide enrolled in the examined 26 destination countries

\begin{tabular}{|c|c|c|c|c|c|c|c|c|c|c|c|c|c|c|}
\hline \multirow[b]{5}{*}{ Country of origin } & \multicolumn{14}{|c|}{ Country of destination } \\
\hline & \multicolumn{14}{|c|}{ OECD Countries } \\
\hline & Austria & \begin{tabular}{|l|} 
Belgium \\
\end{tabular} & \begin{tabular}{|c|} 
Czech \\
Republic
\end{tabular} & Denmark & Finland & France & Germany & Greece & Hungary & \begin{tabular}{|l|} 
Iceland \\
\end{tabular} & Ireland & Italy & Luxembourg & Netherlands \\
\hline & 1 & 2 & & & & & 5 & & & & 6 & & & 5 \\
\hline & CIT & CIT & CIT & CIT & CIT & CIT & CIT & CIT & CIT & CIT & CIT & CIT & CIT & CIT \\
\hline OECD countries & & & & & & & & & & & & & & \\
\hline Austria & a & 46 & 24 & 45 & 39 & 492 & 6419 & 32 & 122 & 15 & 42 & 181 & 5 & 248 \\
\hline Belgium & 117 & $\mathrm{a}$ & 7 & 48 & 28 & 2763 & 963 & 22 & 10 & 1 & 58 & 197 & 95 & 2193 \\
\hline Czech Republic & 622 & 58 & a & 71 & 42 & 751 & 2016 & 10 & 44 & 13 & 29 & 181 & 10 & 143 \\
\hline Denmark & 104 & 37 & 5 & a & 48 & 200 & 492 & 8 & 5 & 68 & 21 & 52 & 4 & 165 \\
\hline Finland & 180 & 41 & 7 & 210 & $\mathrm{a}$ & 284 & 721 & 16 & 21 & 43 & 41 & 79 & 6 & 197 \\
\hline France & 517 & 16650 & 41 & 236 & 153 & a & 5784 & 60 & 63 & 50 & 448 & 1013 & 241 & 822 \\
\hline Germany & 17464 & 675 & 286 & 1461 & 423 & 6918 & a & 393 & 1640 & 103 & 467 & 1591 & 240 & 16554 \\
\hline Greece & 300 & 435 & 151 & 74 & 58 & 1926 & 5627 & a & 166 & 1 & 52 & 4537 & 19 & 670 \\
\hline Hungary & 1391 & 103 & 41 & 166 & 115 & 584 & 2212 & 15 & a & 8 & 21 & 169 & 12 & 261 \\
\hline Iceland & 24 & 5 & 5 & 1747 & 21 & 36 & 89 & 1 & 62 & a & 6 & 7 & 1 & 79 \\
\hline Ireland & 63 & 56 & 48 & 44 & 31 & 392 & 358 & 2 & 127 & 3 & a & 35 & 3 & 125 \\
\hline Italy & 6733 & 1757 & 30 & 223 & 173 & 5009 & 7318 & 91 & 41 & 29 & 233 & a & 63 & 640 \\
\hline Luxembourg & 537 & 1614 & $n$ & 4 & 3 & 1551 & 2562 & 2 & 2 & $\mathrm{n}$ & 10 & 41 & a & 58 \\
\hline Netherlands & 204 & 4056 & 15 & 237 & 80 & 652 & 1544 & 19 & 13 & 10 & 62 & 118 & 8 & a \\
\hline Norway & 74 & 17 & 259 & 2411 & 76 & 324 & 489 & 3 & 700 & 34 & 90 & 69 & $n$ & 329 \\
\hline Poland & 1637 & 494 & 279 & 817 & 190 & 3260 & 13891 & 114 & 44 & 31 & 209 & 1430 & 17 & 844 \\
\hline Portugal & 116 & 770 & 369 & 56 & 31 & 2612 & 1519 & 9 & 19 & $n$ & 33 & 130 & 236 & 282 \\
\hline Slovak Republic & 1470 & 67 & 18621 & 65 & 24 & 399 & 1415 & 6 & 2178 & 8 & 16 & 205 & 8 & 101 \\
\hline Spain & 473 & 886 & 24 & 193 & 122 & 3905 & 4692 & 27 & 50 & 32 & 187 & 504 & 24 & 812 \\
\hline Sweden & 175 & 62 & 112 & 1796 & 532 & 441 & 612 & 25 & 331 & 48 & 71 & 123 & 1 & 201 \\
\hline Switzerland & 708 & 105 & 12 & 81 & 26 & 1613 & 2235 & 33 & 13 & 12 & 20 & 1143 & 1 & 175 \\
\hline Turkey & 2346 & 293 & 53 & 373 & 94 & 2270 & 23881 & 148 & 133 & 4 & 36 & 465 & 4 & 874 \\
\hline United Kingdom & 243 & 241 & 410 & 472 & 200 & 2519 & 1723 & 102 & 104 & 38 & 1421 & 247 & 7 & 827 \\
\hline Total from OECD countries & 35498 & 28468 & 20799 & 10830 & 2509 & 38901 & 86563 & 1138 & 5888 & 551 & 3573 & 12517 & 1005 & 26600 \\
\hline Non-OECD countries & & & & & & & & & & & & & & \\
\hline Albania & 218 & 108 & 49 & 20 & 24 & 437 & 767 & 5940 & 11 & 2 & 7 & 11787 & 4 & 56 \\
\hline Andorra & $n$ & 1 & $\mathrm{n}$ & n & $\mathrm{n}$ & 143 & 1 & $n$ & $\mathrm{n}$ & $\mathrm{n}$ & n & 1 & $\mathrm{n}$ & $\mathrm{n}$ \\
\hline Armenia & 49 & 87 & 52 & 18 & 11 & 482 & 422 & 154 & 5 & $n$ & 1 & 40 & $n$ & 24 \\
\hline Azerbaijan & 47 & 19 & 36 & 8 & 6 & 164 & 445 & 4 & 18 & $\mathrm{n}$ & $n$ & 20 & $\mathrm{n}$ & 29 \\
\hline Belarus & 141 & 70 & 355 & 56 & 25 & 517 & 2096 & $n$ & 14 & $\mathrm{n}$ & 12 & 259 & 2 & 67 \\
\hline Bosnia and Herzegovina & 2742 & 23 & 67 & 272 & 26 & 145 & 2906 & 25 & 10 & 1 & 6 & 374 & 10 & 43 \\
\hline Bulgaria & 1161 & 233 & 123 & 186 & 75 & 2322 & 10552 & 625 & 32 & 9 & 25 & 803 & 18 & 737 \\
\hline Croatia & 1440 & 29 & 72 & 24 & 23 & 122 & 4476 & 12 & 146 & 1 & 11 & 1270 & 3 & 76 \\
\hline Cyprus & 32 & 18 & 172 & 3 & 3 & 242 & 209 & 14377 & 307 & $\mathrm{n}$ & 14 & 106 & $n$ & 36 \\
\hline Estonia & 50 & 17 & 3 & 220 & 681 & 128 & 691 & 8 & 10 & 10 & 13 & 51 & 1 & 65 \\
\hline Georgia & 143 & 36 & 54 & 13 & 6 & 409 & 2705 & 182 & 25 & $n$ & 4 & 74 & 2 & 32 \\
\hline Gibraltar & $n$ & $n$ & $\mathrm{n}$ & $n$ & $\mathrm{n}$ & $n$ & $n$ & $n$ & $n$ & $\mathrm{n}$ & 1 & $n$ & $n$ & $\mathrm{n}$ \\
\hline Holy See & $n$ & $\mathrm{n}$ & $\mathrm{n}$ & n & $n$ & 1 & 1 & n & n & $n$ & $n$ & 3 & $n$ & n \\
\hline Kazakhstan & 51 & 93 & 332 & 14 & 27 & 200 & 989 & 37 & 18 & 5 & 11 & 36 & 1 & 35 \\
\hline Latvia & 62 & 24 & 9 & 239 & 61 & 165 & 848 & 6 & 5 & 11 & 18 & 66 & 3 & 125 \\
\hline Liechtenstein & 163 & $n$ & $\mathrm{n}$ & 1 & $\mathrm{n}$ & 3 & 25 & $n$ & $\mathrm{n}$ & $\mathrm{n}$ & 2 & $n$ & 1 & $\mathrm{n}$ \\
\hline Lithuania & 94 & 39 & 11 & 490 & 99 & 237 & 1577 & 3 & 4 & 22 & 40 & 199 & 3 & 107 \\
\hline Malta & 4 & 4 & $\mathrm{n}$ & 2 & 2 & 17 & 22 & $n$ & 1 & 1 & 6 & 55 & 1 & 7 \\
\hline Moldova & 100 & 42 & 79 & 24 & 11 & 794 & 794 & 98 & 37 & 2 & 8 & 685 & 1 & 25 \\
\hline Monaco & $n$ & 1 & $\mathrm{n}$ & $n$ & $\mathrm{n}$ & 306 & $n$ & $n$ & n & $\mathrm{n}$ & 2 & 8 & $n$ & $\mathrm{n}$ \\
\hline Romania & 897 & 420 & 43 & 285 & 134 & 3844 & 3859 & 163 & 3134 & 5 & 72 & 3151 & 32 & 324 \\
\hline Russian Federation & 588 & 575 & 1405 & 386 & 1291 & 3347 & 12501 & 351 & 204 & 24 & 75 & 949 & 19 & 450 \\
\hline San Marino & $n$ & $n$ & $\mathrm{n}$ & $n$ & $n$ & 1 & 5 & 1 & $n$ & $\mathrm{n}$ & $n$ & 778 & $n$ & $n$ \\
\hline Serbia & 1497 & 103 & 127 & 21 & 12 & 479 & 2177 & 123 & 1310 & 4 & $n$ & 209 & 26 & 48 \\
\hline Slovenia & 653 & 23 & 20 & 18 & 17 & 98 & 606 & 1 & 31 & $n$ & 8 & 328 & 5 & 71 \\
\hline The Former Yugoslav Rep. of Macedonia & 343 & 24 & 63 & n & 6 & 124 & 866 & 58 & 7 & 1 & n & 355 & 3 & 71 \\
\hline Ukraine & 707 & 184 & 907 & 225 & 115 & 1307 & 8787 & 252 & 1372 & 6 & 14 & 737 & 1 & 220 \\
\hline Europe not specified & 25 & 6 & 4 & 173 & n & 741 & 603 & 3 & 11 & 4 & 10 & 33 & n & 54 \\
\hline Total from non-OECD European countries & 11206 & 2179 & 3983 & 2698 & 2655 & 16775 & 58931 & 22423 & 6712 & 108 & 360 & 22377 & 136 & 2702 \\
\hline Total from Europe & 46704 & 30647 & 24782 & 13528 & 5164 & 55676 & 145493 & 23561 & 12600 & 659 & 3933 & 34894 & 1141 & 29302 \\
\hline European Market share, 2008 & 6,3 & 4,1 & 3,3 & 1,8 & 0,7 & 7,5 & 19,5 & 3,2 & 1,7 & 0,1 & 0,5 & 4,7 & 0,2 & 3,9 \\
\hline
\end{tabular}

(Note) The proportion of students abroad is based only on the total of students enrolled in countries reporting data to the OECD and UNESCO Institute for Statistics.

1. Excludes tertiary-type B programmes.

2. Excludes data for social advancement education.

3. Reference year 2007.

4. Excludes private institutions.

5. Excludes advanced research programmes.

6. Excludes part-time students.

(Source) OECD (2010), authors' Calculations 
Table 1. continued

\begin{tabular}{|c|c|c|c|c|c|c|c|c|c|c|c|c|c|c|}
\hline \multirow[b]{5}{*}{ Country of origin } & \multicolumn{14}{|c|}{ Country of destination } \\
\hline & \multicolumn{9}{|c|}{ OECD Countries } & \multirow{4}{*}{$\begin{array}{l}\text { Total OECD } \\
\text { destinations }\end{array}$} & \multicolumn{3}{|c|}{ NON-OECD countries } & \multirow[b]{2}{*}{$\begin{array}{l}\text { Total all } \\
\text { reporting } \\
\text { destinations }\end{array}$} \\
\hline & Norway & Poland & \begin{tabular}{|l|} 
Portugal \\
\end{tabular} & $\begin{array}{c}\text { Slovak } \\
\text { Republic }\end{array}$ & Spain & Sweden & Switzerland & Turkey & $\begin{array}{c}\text { United } \\
\text { Kingdom }\end{array}$ & & Estonia & \begin{tabular}{|l|l} 
Russian \\
Federation
\end{tabular} & Slovenia & \\
\hline & & & & & & & & & & & & 4,5 & & \\
\hline & CIT & $\mathrm{CIT}$ & CIT & CIT & CIT & CIT & CIT & CIT & RES & & CIT & CIT & CIT & \\
\hline \multicolumn{15}{|l|}{ OECD countries } \\
\hline Austria & 50 & 51 & 20 & 71 & 133 & 127 & 1064 & 36 & 1416 & 10678 & 1 & 8 & 16 & 10703 \\
\hline Belgium & 35 & 10 & 80 & 3 & 357 & 54 & 325 & 21 & 2475 & 9862 & 6 & 15 & 2 & 9885 \\
\hline Czech Republic & 51 & 536 & 34 & 2632 & 115 & 62 & 165 & 3 & 1301 & 8889 & $n$ & 18 & 7 & 8914 \\
\hline Denmark & 838 & 20 & 8 & 4 & 70 & 742 & 99 & 8 & 1516 & 4514 & 7 & 4 & 1 & 4526 \\
\hline Finland & 300 & 8 & 12 & 3 & 92 & 2958 & 121 & 2 & 1666 & 7008 & 551 & 55 & 1 & 7615 \\
\hline France & 174 & 94 & 823 & 4 & 1884 & 388 & 4690 & 37 & 12685 & 46857 & 6 & 87 & 6 & 46956 \\
\hline Germany & 756 & 469 & 310 & 222 & 1830 & 1340 & 10960 & 391 & 13625 & 78118 & 24 & 196 & 11 & 78349 \\
\hline Greece & 25 & 22 & 28 & 381 & 184 & 241 & 356 & 875 & 12626 & 28754 & $n$ & 218 & 5 & 28977 \\
\hline Hungary & 43 & 63 & 16 & 88 & 73 & 113 & 203 & 10 & 1026 & 6734 & 1 & 27 & 12 & 6774 \\
\hline Iceland & 267 & 5 & $n$ & 2 & 11 & 369 & 21 & $n$ & 340 & 3098 & 2 & 5 & $n$ & 3105 \\
\hline Ireland & 19 & 19 & 10 & 17 & 74 & 94 & 43 & 2 & 15261 & 16826 & 1 & 1 & $n$ & 16828 \\
\hline Italy & 113 & 54 & 215 & 22 & 3566 & 326 & 4906 & 23 & 5607 & 37171 & 11 & 58 & 100 & 37340 \\
\hline Luxembourg & 3 & 2 & 42 & $n$ & 14 & 6 & 288 & $n$ & 834 & 7573 & $\mathrm{n}$ & $\mathrm{n}$ & $n$ & 7573 \\
\hline Netherlands & 211 & 11 & 55 & 3 & 291 & 249 & 363 & 31 & 3024 & 11256 & 5 & $\mathrm{~m}$ & 3 & 11264 \\
\hline Norway & a & 1014 & 9 & 205 & 82 & 1990 & 78 & $n$ & 2797 & 10250 & 4 & 7 & 1 & 10262 \\
\hline Poland & 230 & a & 160 & 92 & 782 & 564 & 494 & 7 & 8572 & 34158 & 3 & 41 & 13 & 34215 \\
\hline Portugal & 43 & 69 & $\mathrm{a}$ & 10 & 2783 & 97 & 1155 & 1 & 2828 & 13168 & 1 & 2 & 2 & 13173 \\
\hline Slovak Republic & 38 & 119 & 16 & a & 126 & 30 & 165 & 3 & 1116 & 26196 & $n$ & 20 & 8 & 26224 \\
\hline Spain & 182 & 93 & 613 & 13 & a & 326 & 1520 & 8 & 5739 & 20425 & 5 & 28 & 5 & 20463 \\
\hline Sweden & 1290 & 725 & 14 & 49 & 207 & $a$ & 276 & 7 & 3194 & 10292 & 10 & 26 & 1 & 10329 \\
\hline Switzerland & 55 & 6 & 171 & 10 & 319 & 70 & $\mathrm{a}$ & 10 & 1892 & 8710 & 1 & 6 & 3 & 8720 \\
\hline Turkey & 73 & 89 & 29 & 7 & 56 & 251 & 913 & a & 2370 & 34762 & 4 & 345 & 5 & 35116 \\
\hline United Kingdom & 306 & 105 & 99 & 41 & 721 & 525 & 402 & 104 & a & 10857 & 7 & 20 & 1 & 10885 \\
\hline Total from OECD countries & 5102 & 3584 & 2764 & 3879 & 13770 & 10122 & 28607 & 1579 & 101910 & 446156 & 650 & 1187 & 203 & 448196 \\
\hline \multicolumn{15}{|l|}{ Non-OECD countries } \\
\hline Albania & 25 & 88 & 2 & 2 & 79 & 25 & 187 & 590 & 226 & 20654 & $\mathrm{n}$ & 86 & 5 & 20745 \\
\hline Andorra & $n$ & $n$ & 27 & $n$ & 1074 & $n$ & $n$ & $n$ & 10 & 1257 & $n$ & $\mathrm{n}$ & $n$ & 1257 \\
\hline Armenia & 8 & 88 & $n$ & 7 & 126 & 29 & 54 & $n$ & 54 & 1711 & 3 & 3348 & $n$ & 5062 \\
\hline Azerbaijan & 22 & 25 & 1 & 2 & 3 & 30 & 19 & 2014 & 178 & 3090 & 3 & 3689 & $n$ & 6782 \\
\hline Belarus & 84 & 1922 & 10 & 9 & 99 & 120 & 72 & 6 & 156 & 6092 & 23 & 21972 & 3 & 28090 \\
\hline Bosnia and Herzegovina & 149 & 2 & 1 & 12 & 78 & 164 & 219 & 495 & 101 & 7871 & $n$ & 25 & 223 & 8119 \\
\hline Bulgaria & 97 & 104 & 43 & 14 & 890 & 108 & 283 & 1179 & 1251 & 20870 & 5 & 290 & 7 & 21172 \\
\hline Croatia & 53 & 14 & 8 & 16 & 29 & 47 & 356 & 12 & 215 & 8455 & 1 & 16 & 707 & 9179 \\
\hline Cyprus & 2 & 11 & $\mathrm{n}$ & 37 & 21 & 7 & 14 & $n$ & 9795 & 25406 & $n$ & 71 & $n$ & 25477 \\
\hline Estonia & 77 & 12 & 3 & $n$ & 81 & 237 & 24 & 1 & 658 & 3041 & a & 590 & 1 & 3632 \\
\hline Georgia & 9 & 50 & 1 & 3 & 56 & 29 & 44 & 230 & 173 & 4280 & 7 & 2510 & $n$ & 6797 \\
\hline Gibraltar & $n$ & $n$ & $\mathrm{n}$ & $n$ & n & $n$ & $n$ & $n$ & 618 & 619 & $n$ & n & $n$ & 619 \\
\hline Holy See & $n$ & $n$ & $\mathrm{n}$ & $n$ & 14 & $n$ & $n$ & $n$ & 1 & 20 & $n$ & $n$ & $n$ & 20 \\
\hline Kazakhstan & 19 & 426 & 3 & 2 & 18 & 26 & 32 & 709 & 1178 & 4262 & 3 & 35531 & 1 & 39797 \\
\hline Latvia & 95 & 50 & 5 & 1 & 20 & 135 & 53 & $n$ & 1145 & 3146 & 187 & 797 & 3 & 4133 \\
\hline Liechtenstein & n & n & 1 & n & 1 & n & 580 & n & 14 & 791 & n & n & $n$ & 791 \\
\hline 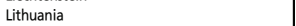 & 166 & 543 & 8 & n & 92 & 196 & 64 & 9 & 1968 & 5971 & 57 & 841 & 3 & 6872 \\
\hline Malta & 2 & n & $n$ & 2 & 73 & 2 & 8 & $n$ & 820 & 1029 & $n$ & 1 & $n$ & 1030 \\
\hline Moldova & 24 & 89 & 68 & 5 & 152 & 22 & 55 & 165 & 76 & 3356 & 4 & 3771 & 2 & 7133 \\
\hline Monaco & 1 & n & n & $n$ & 1 & $n$ & 5 & $n$ & 47 & 371 & n & n & $n$ & 371 \\
\hline Romania & 169 & 48 & 114 & 86 & 2424 & 193 & 565 & 66 & 1179 & 21206 & 5 & 26 & 10 & 21247 \\
\hline Russian Federation & 868 & 459 & 96 & 64 & 817 & 583 & 757 & 524 & 2646 & 28978 & 1190 & a & 32 & 30200 \\
\hline San Marino & $n$ & $n$ & $\mathrm{n}$ & n & 1 & $n$ & 2 & $n$ & 13 & 801 & $n$ & $n$ & $n$ & 801 \\
\hline Serbia & 28 & 32 & 15 & 225 & 17 & 24 & 870 & 242 & 124 & 7713 & $n$ & 158 & 131 & 8002 \\
\hline Slovenia & 4 & 9 & 8 & 4 & 35 & 15 & 41 & 2 & 285 & 2282 & $n$ & 7 & $\mathrm{a}$ & 2289 \\
\hline The Former Yugoslav Rep. of Macedonia & 8 & 19 & 4 & 5 & 19 & 36 & 237 & 332 & 89 & 2670 & 1 & 26 & 202 & 2899 \\
\hline Ukraine & 203 & 2877 & 127 & 105 & 606 & 241 & 268 & 183 & 495 & 19939 & 102 & 12101 & 25 & 32167 \\
\hline Europe not specified & 152 & $n$ & $\mathrm{n}$ & 6 & 37 & 2 & 2193 & $n$ & 232 & 4289 & $n$ & $n$ & 2 & 4291 \\
\hline Total from non-OECD European countries & 2265 & 6868 & 545 & 607 & 6863 & 2271 & 7002 & 6759 & 23747 & 210172 & 1591 & 85856 & 1357 & 298976 \\
\hline Total from Europe & 7367 & 10452 & 3309 & 4486 & 20633 & 12393 & 35609 & 8338 & 125657 & 656328 & 2241 & 87043 & 1560 & 747172 \\
\hline European Market share, 2008 & 1,0 & 1,4 & 0,4 & 0,6 & 2,8 & 1,7 & 4,8 & 1,1 & 16,8 & 87,8 & 0,3 & 11,6 & 0,2 & 100,0 \\
\hline
\end{tabular}

(Note) The proportion of students abroad is based only on the total of students enrolled in countries reporting data to the OECD and UNESCO Institute for Statistics.

1. Excludes tertiary-type B programmes.

2. Excludes data for social advancement education.

3. Reference year 2007.

4. Excludes private institutions.

5. Excludes advanced research programmes.

6. Excludes part-time students.

(Source) OECD (2010), authors' Calculations 
These results are better illustrated in Figure 3.

Figure 3: Incoming foreign student percentage market shares for the 26 examined European destination countries.

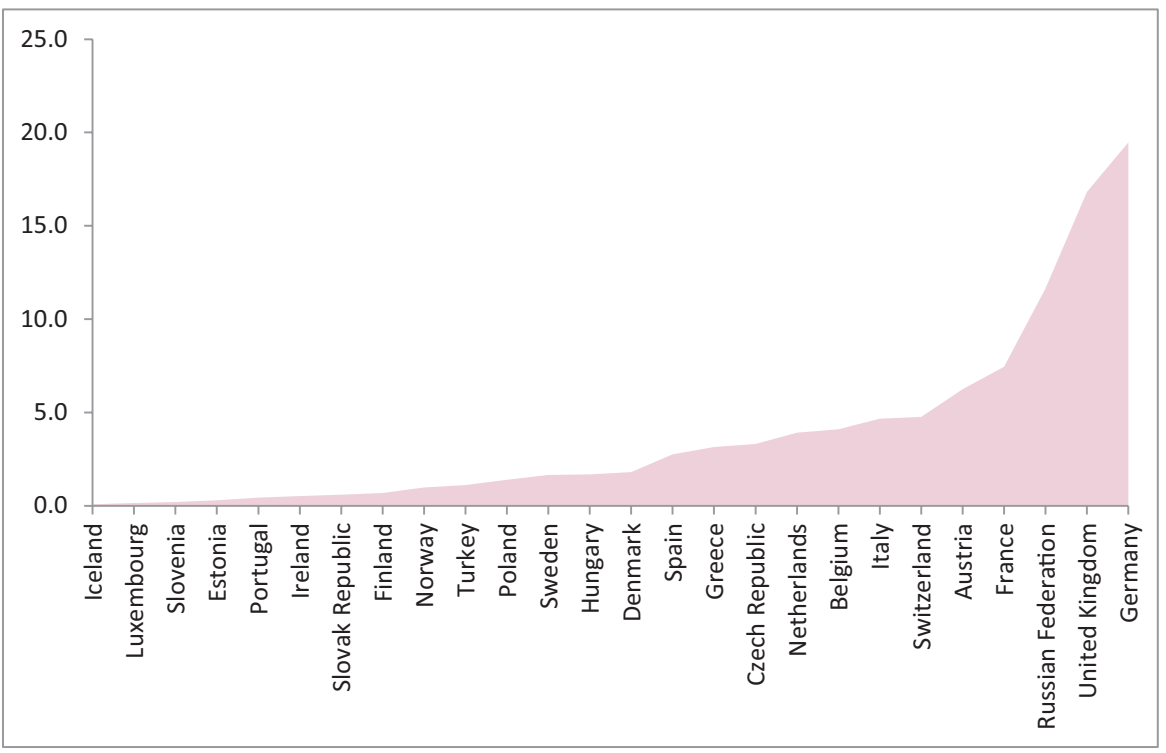

It can be deduced that the major European destination countries (in increasing order of intra-European market foreign student shares) are Netherlands, Belgium, Italy, Switzerland, Austria, France, Russia, the UK, and Germany, having a total share of 79.2\%. Consequently, the vast majority of European students that decide to study in a European country other than their own enroll to one of these nine countries. An interesting fact is that these percentages differ significantly compared with the respective distribution of worldwide foreign students (OECD , 2010). Also, Germany is the most attractive country for European students that study abroad. On the other hand, the UK and France are much more diverse markets and attract many students from Asia, Africa, etc. Finally, it seems that the size of the country is not directly related to its foreign student market share as, for example, the UK and Germany are considerably smaller countries than Russia, but their market shares are greater.

It can be concluded, at least in terms of the intra-European market, that European countries with high foreign student market shares and high incoming mobility can be regarded as "net exporters" of academic qualifications, while the opposite is true for the remaining countries, i.e. they are "net importers" of academic qualifications. This is something that becomes more evident in Figure 4, which illustrates the incoming/outgoing student ratios for the 26 countries examined. 
Figure 4. Incoming/outgoing student ratios for the 26 examined European destination countries

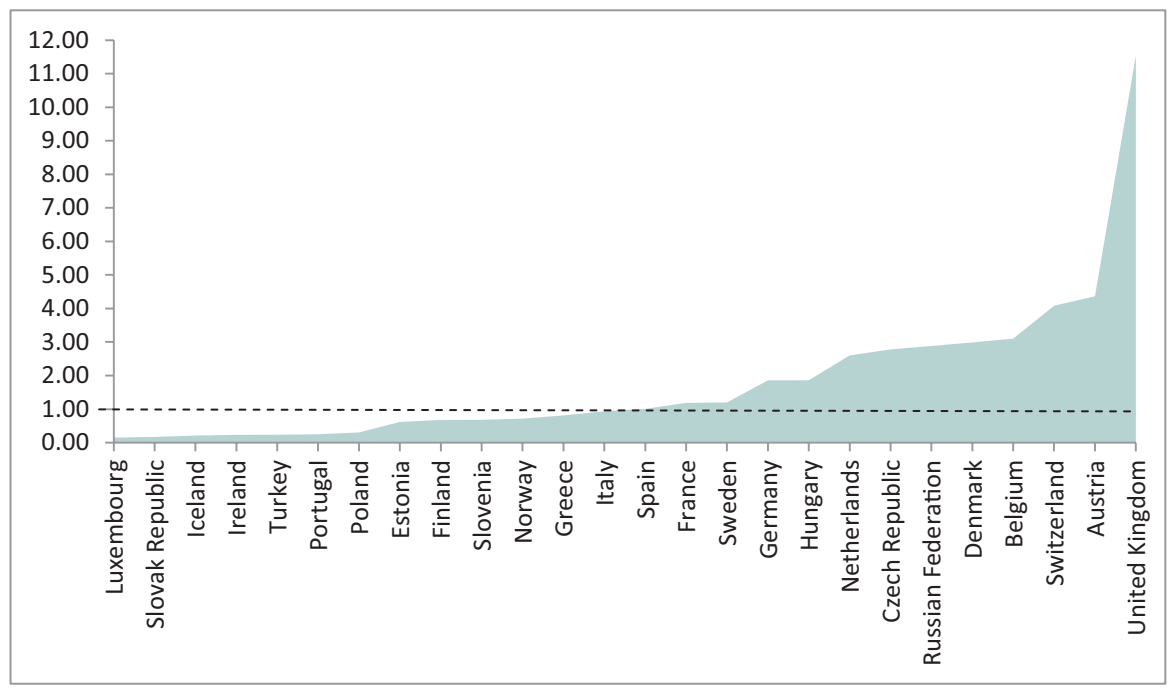

For the countries with a ratio greater than 1 , although only inside the relatively limited European student market compared with the global market, it is obvious that they can be considered as academic qualification exporters, whereas the remaining countries can be considered as academic qualification importers. Compared with Figure 3, significant differences exist as it is evident that countries with high student market shares have comparatively lower ratios and vice versa. For example a UK student, having a high quality tertiary educational system, seems not to be very interested in studying abroad. Finally, it is quite reasonable to assume, although there is no reliable data available yet, that the majority of the remaining 24 European countries that were not considered as destinations in the previous analysis are academic qualification importers.

\section{B. Erasmus student mobility}

Student exchange programs are excluded theoretically from the UOE data on mobility. These programs are characterized by a relatively short duration (usually of one academic semester), and they are called "exchanges" because originally the goal was an exchange of students between different countries. No trade-off is actually required; therefore, a student is allowed to go to another country without finding a counterpart in that country to exchange with. Various European programs were created to support learning mobility across Europe. The most famous of them is probably Erasmus, often considered the European Union's flagship mobility program.

Erasmus data do not present the volume of exchanges, i.e. the number of students, but they 
do present the number of visits abroad by those participating in the related programs. In Figure 5, the percentages of incoming Erasmus students for 24 countries (the 26 countries examined in the previous section excluding Russia and Switzerland) for the academic year 2008 2009 are illustrated ${ }^{8}$. Comparing Figures 3 and 5, although the countries with high foreign student market shares in Europe attract many Erasmus students, significant differences exist because of the short-term nature of the program and the co-operation between the educational institutions of the host and origin countries.

Figure 5. Percentages of incoming students under the Erasmus program

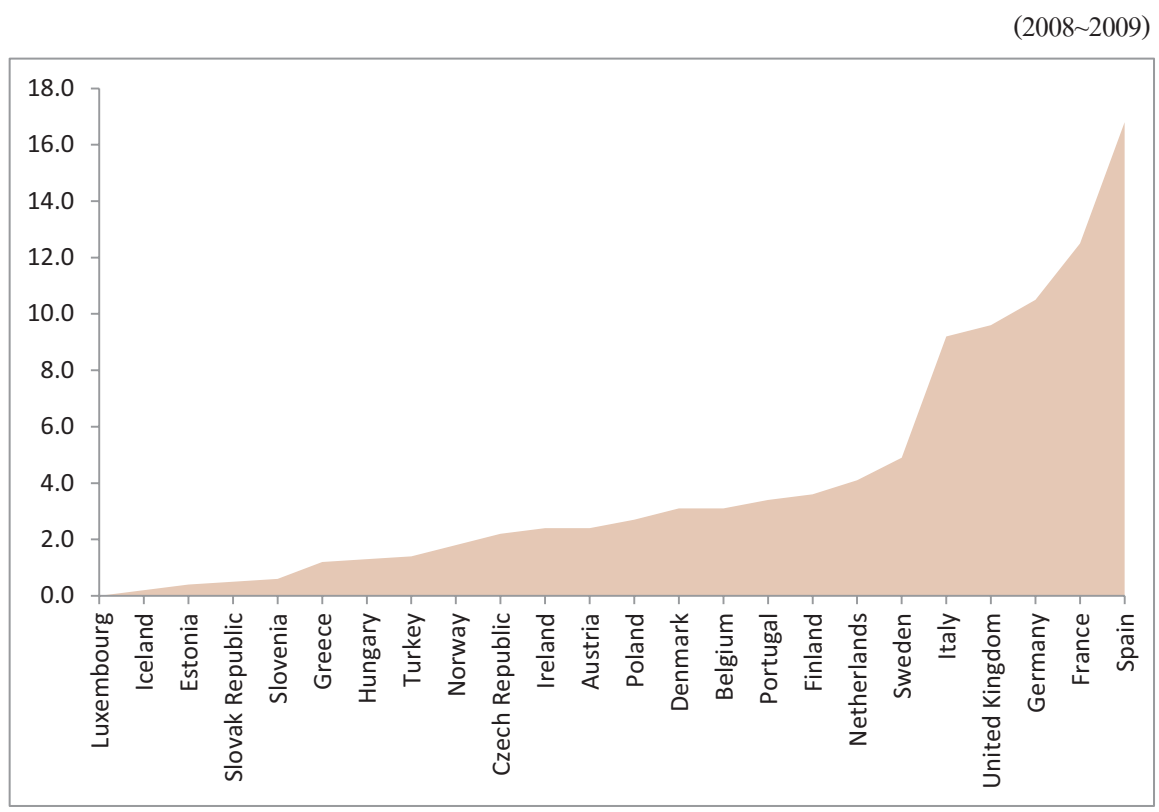

\section{Statistical Analysis}

The objective of the developed statistical models in this section is to estimate the percentage market shares of foreign students and the incoming/outgoing student ratios of the 26 destination European countries by modeling their correlation with some of the major factors that may affect student choice regarding the country of study. The short term mobility of students under the Erasmus program is excluded from the following analysis and left as an open research topic for the future. The main reason for this exemption is that the nature of the Erasmus program

\footnotetext{
${ }^{8}$ http://ec.europa.eu/education/erasmus/doc920_en.htm
} 
and the existing agreements between the educational institutions of host and origin countries constitute factors that affect student decision making regarding the selection of a country for study.

At this point it should be noted that our data may underestimate the number of students studying abroad. Indeed, data on international and foreign students in the UOE statistical surveys used are obtained from enrolments in destination countries. As Tremblay (2001) mentions, students are usually counted on a specific day or period of the year and this can provide an estimate of the proportion of foreign enrolments in an education system, but the actual number of individuals involved may be much higher since many students study abroad for less than a full academic year or participate in exchange programs that do not require enrolment, for example, inter-university exchange or advanced research short-term mobility. Unfortunately, there is no data regarding the exact percentage of this underestimation yet. Statistical analysis was performed using the SPSS for Windows version 17 package and a significance level of $5 \%$.

An estimation of the percentage market shares of foreign students and the incoming/ outgoing student ratios of the 26 destination European countries presented in Section III is attempted. It has to be stressed that relevant time series are not yet available regarding foreign students mobility; therefore, the following variables were selected using data from the year 2008, which were the latest available regarding foreign students (OECD, 2010):

PERC: Foreign student percentage market shares.

RATIO: Incoming/outgoing student ratios.

UNIRANK: Quality of University Ranking as a proxy of the perceived quality of the tertiary educational institution.

According to the Academic Ranking of World Universities (ARWU) at http://www.arwu. org/Europe2009.jsp compiled by Shanghai Jiao Tong University and now maintained by the Shanghai Rankings Consultancy, normalized values summing up to one were assigned to the 26 countries, quantifying and rating the perceived quality of tertiary educational institutions.

GDP: Gross Domestic Product per capita (in thousand euros) (www.cia.gov).

UNEMPL: Unemployment percentage rates (OECD, 2010).

COMP: Employees' compensation (in million euros) (OECD, 2010).

$C P L$ : Logarithms of Comparative Price Levels (http://epp.eurostat.ec.europa.eu).

Some descriptive statistics for variables $P E R C$ and $R A T I O$ are illustrated in Table 2.

Table 2. Descriptive statistics for variables PERC and RATIO

\begin{tabular}{|l|c|c|c|c|c|c|c|c|c|}
\hline & $\mathrm{N}$ & Minimum & Maximum & Mean & Std. Deviation & \multicolumn{2}{|c|}{ Skewness } & \multicolumn{2}{|c|}{ Kurtosis } \\
\cline { 2 - 10 } & Statistic & Statistic & Statistic & Statistic & Statistic & Statistic & Std. Error & Statistic & Std. Error \\
\hline PERC & 26 & 0.10 & 19.50 & 3.8538 & 5.01033 & 2.102 & .456 & 4.134 & .887 \\
RATIO & 26 & 0.15 & 11.54 & 1.8250 & 2.35009 & 3.048 & .456 & 11.676 & .887 \\
Valid N (listwise) & 26 & & & & & & & & \\
\hline
\end{tabular}


Then the continuous variables PERC and RATIO were tested to determine whether or not they follow the normal distribution by using a one-sample Kolmogorov-Smirnov nonparametric test. This test is used to compare a sample with a reference probability distribution, which in the case examined is the normal distribution. The Kolmogorov-Smirnov statistic quantifies a distance between the empirical distribution function of the sample and the cumulative normal distribution function. The null distribution of this statistic is calculated under the null hypothesis that the sample is drawn from the normal distribution (normality assumption).

For both variables the normality assumption is not violated ( $p$-value $=0.10$ and 0.11 , respectively). Since normality was ensured, a regression analysis was performed with $P E R C$, in the first case, and RATIO, in the second case, as the dependent variable in order to assess their correlation with the other four independent variables, a methodology used or proposed by many researchers such as Altbach and Teichler (2001), Altbach and Knight (2007), Guruz (2008), Agiomirgianakis (2006), Agiomirgianakis et al. (2004), and Agiomirgianakis and Asteriou (2001). Indeed, in the first case, where the dependent variable is the percentage market share of foreign students in the destination countries, it is reasonable to assume that it is significantly correlated with the quality of the tertiary education system. This is illustrated in Figure 6.

Figure 6. Foreign student percentage market shares vs. Normalized university ranking

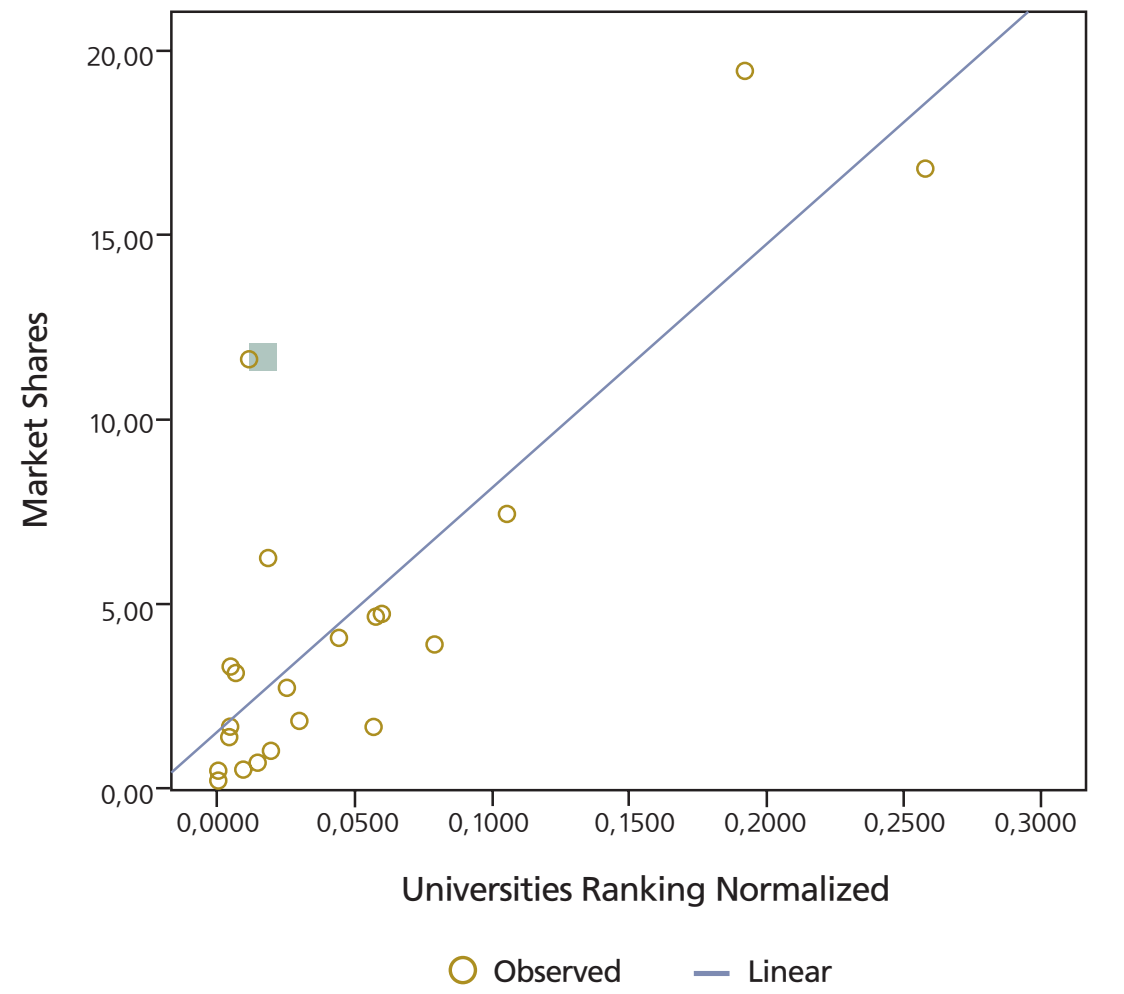


From Figure 6, it is obvious that, with the exception of the Russian Federation, which is depicted by the black square around the dot, a linear equation with UNIRANK fits $P E R C$ data adequately. Consequently, a linear regression model with five independent variables (UNIRANK, GDP, UNEMPL, COMP and CPL) was tested. The statistically significant independent variables are $U N I R A N K\left(p\right.$-value $\left.=2.195 \cdot 10^{-9}<0.05\right)$ and $C P L$ $(p$-value $=0.007<0.05)$. Multicollinearity, i.e. the case where two or more independent variables in a linear regression model are highly correlated, does not exist between them and the model's $R^{2}=0.7958$, which indicates that the model fits PERC data well, explaining $79.58 \%$ of their variability. The estimated linear equation is:

$$
\widehat{P E R C}=26.555+74.025 \text { UNIRANK-12.881CPL }
$$

The other three variables were not statistically significant. This may be explained by students basing their decision to study abroad mostly on the academic reputation of the destination country and on the cost of living there. The negative sign in CPL may be explained by the decrease in the number of incoming students in a country if the cost of living in that country for a student is high, including tuition fees, rental cost, etc.

An interesting observation is that the high percentage market share of foreign students in the Russian Federation, even though the ranking score of its universities is not very high, may be explained by a number of reasons such as (a) the large number of students that it attracts from its neighboring countries and (b) historical reasons dating from the policy of the ex-Soviet Union, which create both an agglomeration effect and a language-familiarization effect. Thus, the case of the Russian Federation is something that is worth investigating further in the next section.

In the second case where the incoming/outgoing student ratio is considered as the dependent variable, the linear regression model with the five independent variables used was tested. A single statistically significant independent variable was observed, namely UNIRANK (with $p$-value equal to 0.000008 ). The model's $R^{2}=0.779$, which indicates that the model fits $R A T I O$ data well, explaining $77.9 \%$ of their variability. The estimated linear equation is:

$$
\text { RATIO }=1.81+52.67 \text { UNIRANK }
$$

The residuals' descriptive statistics for the two models are illustrated in Table 3. 
Table 3. Descriptive statistics for the residuals for the two regression models

\begin{tabular}{|l|c|c|c|c|c|c|c|c|c|c|c|c|}
\hline & $\mathrm{N}$ & Range & Minimum & Maximum & \multicolumn{2}{|c|}{ Mean } & \multicolumn{2}{|c|}{ Std. Deviation } & Variance & \multicolumn{2}{|c|}{ Skewness } & \multicolumn{2}{|c|}{ Kurtosis } \\
\cline { 2 - 11 } & Statistic & Statistic & Statistic & Statistic & Statistic & Std. Error & Statistic & Statistic & Statistic & Std. Error & Statistic & Std. Error \\
\hline $\begin{array}{l}\text { Unstandardized Residual } \\
\text { - model 1 }\end{array}$ & 21 & 8.00261 & -4.04000 & 3.96261 & $0 \mathrm{E}-7$ & .39480729 & 1.80923427 & 3.273 & .130 & .501 & .642 & .972 \\
$\begin{array}{l}\text { Unstandardized Residual } \\
\text { - model 2 } \\
\text { Valid N (listwise) }\end{array}$ & 19 & 4.80992 & -2.16098 & 2.64894 & $0 \mathrm{E}-7$ & .28334997 & 1.23509389 & 1.525 & .310 & .524 & -.400 & 1.014 \\
\hline
\end{tabular}

Consequently, although a number of factors are examined in an effort to find which ones may significantly affect the flow of foreign students, one can safely conclude that the quality competiveness of a country's tertiary education system enhances the country's market share in the foreign student educational market both by attracting students and by deterring native students from migrating abroad. Living-cost considerations are also important in attracting international students.

\section{Estimating Probability of Student's Mobility}

An interesting research topic is the estimation of the probability of students moving from one European country to another and attempting to discover the reasoning behind their decision. For example, describe the "profile" of Germans and French that study in Austria and Belgium, respectively, explain why Russian Federation attracts students from its neighboring former USSR countries, why Greece enrolls large number of Cypriot and Albanian students, etc. Accordingly, factors affecting student decisions that originate from their own countries, including any implications arising from the several kinds of relationships between European countries, will be incorporated in the analysis.

The developed statistical model's objective is to estimate the probability of students moving from one European country to another and attempting to discover the reasoning behind their decision in a quantitative way. The drivers and barriers of student mobility can be categorized into those that have national-international characteristics and those that are based on the personal profile features of students. The present analysis focuses on the first group, where the examined major underlying factors that either enhance or discourage students in selecting a country of study are: language, financial aspects, immigration policy/migration networks in host countries, perceived academic superiority of the institutions in the host countries, and geographical-ideological-cultural affinity. These factors were proposed by Altbach and Knight (2007) and Guruz (2008).

The methodology utilized was decision trees analysis and, more specifically, a univariate- 
split CART (Classification and Regression Trees) algorithm by Breiman et al. (1984). For the 26 destination and the 50 origin European countries, all the possible pairs were formed and, after excluding not applicable and unavailable data, a sample of 1,109 pairs was created. Then for each case the following variables were selected:

(1) Mobility_origin_ordinal: According to Table 1, the numbers of foreign students enrolled in tertiary education by country of origin were transformed to percentages, which in turn were classified into three categories of probability level, namely Low, Medium, and High, which each included approximately $50 \%, 40 \%$, and $10 \%$ of the cases respectively, arranged in non-decreasing order of the percentage of students enrolled from the origin country.

(2) University Ranking Normalized: The variable UNIRANK used in the previous regression analyses.

(3) GDP: the same as in the previous analyses.

(4) Distances: a binary variable indicating if two countries have common geographical borders.

(5) Language: a binary variable indicating if two countries have the same official state language.

(6) Culture: a binary variable indicating if two countries have significant cultural similarities according to Ronen and Shenkar (1985) and the authors' opinion.

(7) Immigration Index: a binary variable indicating if there is a significant population minority (higher than $0.1 \%$ of the total population) from the origin country in the destination country (Eurostat, 2009a and 2009b).

CART algorithm was then implemented with Mobility_origin_ordinal as dependent variable and the remaining six items from the above list as the predictor independent variables. For all the statistical tests, a significance level of 5\% was used. The resulting tree diagram is illustrated in Figure 7. 
Figure 7. CART algorithm tree diagram

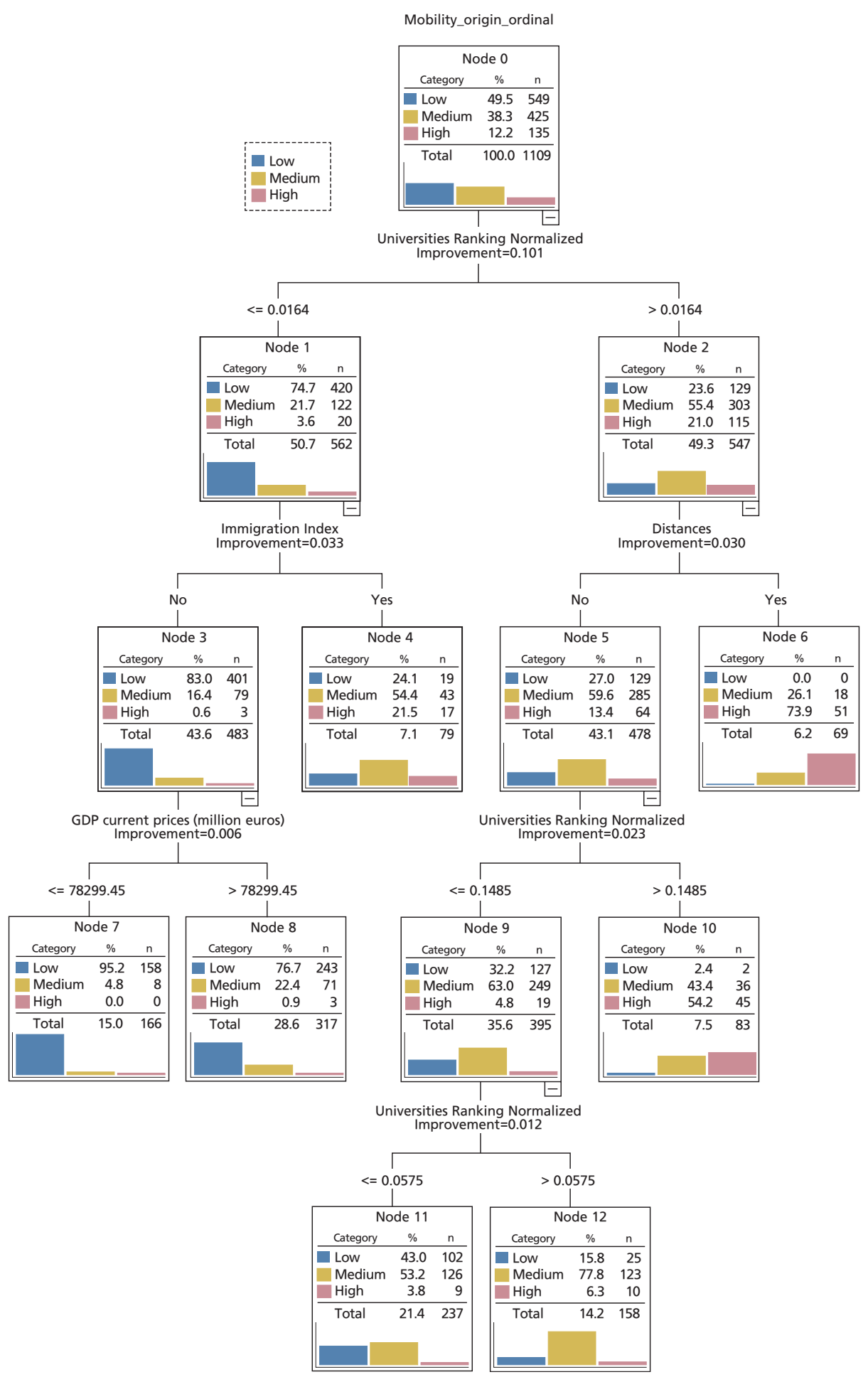


The tree diagram displays detailed results within each node, which are numbered. The results of the CART tree show 7 sample segments that yield different probabilities for students to move from their origin to a destination country, details for which are displayed in each of the tree's 7 terminal nodes. The largest percentage of high student mobility is obtained from segment 6 , defined as pairs of countries with common geographical borders and a normalized university ranking above 0.0164 . Terminal node 6 shows that there are a total of 69 pairs of countries in this segment and the percentage of high student mobility between them is $73.9 \%$. This explains the fact that many Germans study in Austria, French in Belgium, etc. The next high student mobility segment is obtained from pairs of countries where the destination countries have very high normalized university ranking, i.e. Germany and the UK (terminal node 10 ), and the percentage of high student mobility to these two countries is $54.2 \%$. Segment 4 is also worth mentioning, which contains cases where the destination countries have a tertiary educational system that is not considered of very high quality, but they have a significant population minority from the origin country (for example the Russian Federation attracts students from its neighboring former USSR countries, Greece enrolls large numbers of Cypriot and Albanian students). The percentage of high student mobility in terminal node 4 is $21.5 \%$. The implementation of the CART algorithm classifies correctly the percentage of foreign students by country of origin in $71.1 \%$ of the cases (Table 4).

Table 4. CART algorithm- observed vs. predicted cases

\begin{tabular}{|c|c|c|c|c|c|}
\hline \multirow{4}{*}{} & \multicolumn{5}{|c|}{ Predicted } \\
\cline { 2 - 6 } & & Low & Medium & High & Percent Correct \\
\cline { 2 - 6 } & Low & 401 & 146 & 2 & 73.0 \\
\cline { 2 - 6 } & Medium & 79 & 292 & 54 & 68.7 \\
\cline { 2 - 6 } & High & 3 & 36 & 96 & 71.1 \\
\cline { 2 - 6 } & Overall Percentage & 43.6 & 42.7 & 13.7 & 71.1 \\
\cline { 2 - 6 } & & & &
\end{tabular}

\section{Conclusions}

The political and economic importance of international student mobility and the efforts taken by the EU to increase it have resulted in an enhanced need for comprehensive, up-todate, and reliable estimates. To satisfy this need, information about the effects of mobility and statistical data are required. While the plethora of statistical surveys published by national governments, specialized agencies, research institutes, and international organizations, such as 
the OECD, UNESCO, and the EU, may give the impression that there is no shortage of quality data on foreign/international student mobility, this is a rather misleading impression because the available data are not (always) the data that is needed as stated by Kelo et al. (2006b). The data limitations are widely known and have been thoroughly explained and accepted by scholars and public services. In addition, there is a large requirement for inferential statistical analysis.

Tertiary education institutions play a major role in equipping students with the tools to overcome the threat of unemployment by offering academic qualifications and the opportunity for students to develop their skills and abilities; however, it must be accepted that student mobility between European countries is not balanced. Several patterns based on geographical affinity and migration networks and a flow of students towards large European countries with advanced tertiary educational systems are visible. This inequality could be attributed, to some extent, to fund shortages in some parts of Europe, but it may also result from a short-sighted vision of the dynamics of cooperation. European countries are characterized by a diversity of languages, cultures, religions, and priorities that have resulted in segmented national/ethnic markets with regard to academic qualifications. Unfortunately, this diversity has been seen to a large extent as an obstacle rather than as an advantage for achieving a European identity.

Using quantitative methodology, this paper shows that the percentage market share of foreign students of a country is positively related to the academic quality of that country's tertiary education system and negatively related to a high cost of living. Also, the ratio of incoming/outgoing students in a destination country depends positively on the academic quality of its tertiary education system. Finally, an estimation was done for the probability of students moving from one European country to another.

The aforementioned results have some clear policy implications: First, if a country aims to enhance its share in the foreign student educational market then it should significantly improve the competitiveness of its tertiary education system. Second, foreign student mobility may be affected positively in the near future because of a rapid increase of immigration and generic citizen mobility within Europe as a result of both institutional measures undertaken by the EU and the seriousness of the economic crisis that has occurred in several (mostly southern) European countries. Decisions about studying abroad have to be made in consideration of livingcosts and a student's budget for education. In countries with more stable financial conditions student decisions may be less affected by high living-costs, whereas students in countries affected by the crisis may choose less expensive destinations and public rather than private institutions (OECD, 2010). Policy measures towards increasing student mobility flows will not only extend economic integration of the countries involved via human capital development, but they are also most likely to increase tangible present and future economic flows. Provided that consistent time series regarding student mobility are available, the next research step would be to utilize more extensive data, i.e. add more years to the empirical analysis in this paper so as to form panel data, thereby increasing the efficiency of the estimators. Finally, 
it has to be noted that there are several other factors that affect student choices that could be examined in future research, such as the transparency and flexibility of programs regarding the time spent abroad towards degree requirements, the restrictive university admission policies of origin countries, and government policies to facilitate transfer of credits between home and host institutions.

Received 13 December 2012, Revised 23 February 2013, Accepted 26 February 2013

\section{References}

Agiomirgianakis, G. (2006). European Internal and External Migration: Theories and Empirical Evidence in Zervoyianni, A., Argiros, G. and Agiomirgianakis, G. (Eds.), European Integration, Palgrave (Macmillan) Press Limited, Hampshire, UK, chapter 10.

Agiomirgianakis G., Lianos, T. and Asteriou, D. (2004). Foreign Universities Graduates in the Greek Labour Market. International Journal of Finance and Economics 9, 151-164.

Agiomirgianakis, G. and Asteriou, D., (2001). Human Capital and Economic Growth: Time Series Evidence in the case of Greece. Journal of Policy Modelling, 23, 481-489.

Altbach, P.G. and Knight, J. (2007). The Internationalization of Higher Education: Motivations and Realities. Journal of Studies in International Education 11, 290-305.

Bologna Follow Up Group (2003). Bologna Process between Prague and Berlin. Report, Berlin.

Breiman, L., Friedman, J.H., Olshen, R. and Stone C.J. (1984). Classification and Regression Tree. Wadsworth \& Brooks/Cole Advanced Books \& Software, Pacific California.

ESIB (The National Unions of Students in Europe) (2007). Promoting Mobility. A Study on the Obstacles to Student Mobility: Berlin.

European Students' Union (2009). Bologna with Students Eyes: Leuven.

Eurostat (2009a). The Bologna Process in Higher Education in Europe. Key indicators on the social dimension and mobility: Luxemburg.

Eurostat (2009b). Key Data on Education in Europe 2009. European Commission: Brussels.

EUROSTUDENT III (2008). Social and Economic Conditions of Student Life in Europe. Bielefeld.

HEFCE (2004). International Student Mobility. Sussex.

Guruz, K. (2008). Higher Education and International Student Mobility in the Global Knowledge Economy. State University of New York Press, Albany.

Kehm, B.M. (2005). The Contribution of International Student Mobility to Human Development and Global Understanding. US-China Education Review, 2, 1: 18-24.

Kelo, M., Teichler, U. \& Wächter, B. (2006a). EURODATA. Student Mobility in European Higher Education. Bonn, Germany.

Kelo, M., Teichler, U., Wächter, B. (2006b). Toward Improved Data on Student Mobility in Europe: Findings 
and Concepts of the Eurodata Study. Journal of Studies in International Education, 10: 194-223.

Lanzendorf, U. and Teichler, U., (2003). Statistics on student mobility within the European Union (European Parliament EDUC 112 EN). Luxembourg City, Luxembourg: Office for Official Publications of the European Communities.

OECD, (2010). Education at a Glance 2010. OECD Indicators: Paris.

Ronen, S. and Shenkar, O., (1985). Clustering Countries on Attitudinal Dimensions: A Review and Synthesis. Academy of Management Review 10, 435-454.

Szarka, J. (2003). Student Mobility in the EU. European Integration Studies, Miskolc, 2, 2: 123-138.

Tremblay, K. (2001). Student mobility between and towards OECD countries: A comparative analysis. OECD International Mobility of the Highly Skilled, Paris: 39-67.

Van Bouwel, L. and Veugelers, R. (2010). Does university quality drive international student flows? Working paper, Leuven University.

Varghese, N.V. (2008). Globalization of higher education and cross-border student mobility. IIEP, Paris, France.

Verbik, L., Lasanowski, V. (2007). International Student Mobility: Patterns and Trends. Report of the Observatory of borderless higher education, London, UK.

\section{Appendix. Web-pages available on 20 October 2012}

http://www.oecd.org/edu/eag2009

http://www.ond.vlanderen.be/hogeronderwijs/Bologna

http://circa.europa.eu/Public/irc/dsis/edtcs/library?l=/public/unesco_collection

http://ec.europa.eu/education/erasmus/doc920_en.htm

http://www.timeshighereducation.co.uk/world-university-rankings/2010-2011/europe.html

http://www.arwu.org/Europe2009.jsp

http://www.cia.gov

http://epp.eurostat.ec.europa.eu 